\title{
OCCURRENCE OF DUST MITE, OLIGONYCHUS AFRASIATICUS MEG. ON FRUITS, LEAFLETS OF SOME DATE PALM TREES AND EVALUATION THE EFFICIENCY OF BOTANICAL COMPOUND, (BIACO) AS COMPARED WITH SOME ACARICIDES
}

\author{
Saleh, A. Aldosari \\ Department of Plant Protection, College of Food Science and Agriculture, King Saud University, \\ Riyadh, 11451, Box. 2460, Saudi Arabia Kingdom
}

\begin{abstract}
:
This work was carried out in El-Karg region at Riyadh Governorate, which is representating the whole region, because of the similarity of the terrain, growing conditions and the passage of planting material throughout the years, on fruits\& leaflets of some date palm during season 2007.

Occurrence of dust mite, Oligonychus afrasiaticus Meg. On date (fruits and leaflets) and evaluation the efficiency of the botential compound "Biaco" as compared with some acaricides searching for other safer compound for controlling this mite species were studied, during season 2007.

1-Data showed that the active period of Oligonychus afrasiaticus mite occurred throughout the period from the first half of March until second half of October 2007. Number of mites/100 date fruits reached its maximum with 9095.5 mites/100 dates on the $26^{\text {th }}$ of July, then population was gradually decreased till the middle of October 124 mite 100 date fruits.

2-The mean percentages of infestation began after the $2^{\text {nd }}$ week of March and reached $3 \%$, while it was in its maximum on the $3^{\text {rd }}$ week of October (80\%).

3-Statistical analysis of the data revealed significant differences between botanical compound (Biaco) as compared with the other acaricids (amitraz, vertimec, perpol and salocide). Regardless of fruits date cultivars good results were achieved when applied all acaricides, while Biaco 1-500 ml gave satisfaction results as compared with the other five compounds tested against the dust mite.

4-The reductions of the mite population on leaflets of botanical compound Bicao were 17.6, 3.8, 10.6 and 12.6. Bicao ranked the first number, which Salocide EC (150 mL.) may indicate that they lost their efficacy when applied against this mite species on date cultivars of Nabotsif, Sokary, Kalas and Sakiey date varieties, $(26.2,14.40,20.10$ and 18.80$)$ on leaflets respectively.
\end{abstract}

\section{INTRODUCTION:}

The dust mite, Oligonychus afrasiaticus Meg. (Acari: Tetranychidae) is considered one of the most important pest infesting some economic crops in Saudi Arabia. The old world date mite, $O$. afrasiaticus, is a serious pest of dates in North Africa and the Near
East.Palevsky et al. (2005) and Talhouk (1991), reported that this mite caused very serious damage to fruits in orchards in Dirab, Unayzah and Al Sulayell districts. It attacks the dates from their early stages of development, spinning its webs around the date bunches and multiplies in big numbers. Dust collected in the webs plus the exuviae of different development stages of 
the mite, thus making the dates bunches look dusty (Saleh and Hosny, 1979). It feeds on juices, sucks from the date, rendering them unfit for human consumption (Mohamed, 2005). Hussein (1969) reported that this pest has 6 generations/year, the peak number of the mite was occurred around the middle of July/in Iraq. Gerson et al. (1983) observed that O.afrasiaticus had been found on the grasses Cynodon dactylon (L). and Impeata cylindrical (L) planted among date palms in Israel. The infestation of this mite species usually starts around mid of May to June when it builds dusty, creamy silken webs on date bunches around stands date fruits, where adults and immatures live.

Sever infestation with mite resulting in economic reduction in the quality and quantity of crop production. Although chemical control of mites is an old tool, it is yet still necessary for controlling the pest as an effective method.

Many acaricides are available in the Saudi markets in order to control the mite on date palm trees but their efficacy against the date mite is questionable (Palevsky et al., 2003 and Mohammed, 2005).

Thus, the present work aimed to study the occurrence and fluctuation of date palm mite, in addition to evaluate the efficiency of the potential compound "Biaco" and some acaricides against dust mite.

\section{MATERIALS AND METHODS:}

The occurrence and fluctuation of date dust mite, $O$. afrasiaticus on date fruits:

This experiment was carried out in El-Karg region at Riyadh Governorate.

Samples of one hundred date fruits was collected from each of the $\mathbf{2}$ date palm cultivars (Nabotsif andSokary) during season 2007.
Samples were periodically taken at seven days intervals from the $2^{\text {nd }}$ week of March, until the $3^{\text {rd }}$ week of November 2007.

The mites were removed using fine brunch onto slide, then counted by means of stereobinocular microscope and percentages of infestation of the different sampling dates were recorded.

The efficiency of botanical compound, (Biaco) as compared with some chemical acaricides against $O$. frasiaticus on fruits and leaflets of some date palm cultivars:

\section{A-On Date fruits:}

The experiment was carried out during season 2007. Sample of one hundred date fruits was collected from each of the four date palm cultivars (Nabotsif, Sokary, Kalas, and Sakiey) in El-Karg at Riyadh Governorate. The tested acaricides and their application rates were as follows:

Botanical compound "Baico" $1-500 \mathrm{ml}$ (Matrine 0.36\%), Amitraz 20\% EC (100 mill.), Vertimec 1.8\% EC (40 mill.), Perpol 25\% WP (25gr.) and Salocide EC 150 mill, (Methidathion $40 \%$ ). Each treatment was applied with 100 Lit. Water.

The numbers of the mite, moving stages were counted after on month.

\section{B-On Date leaflets:}

The experiment was carried out during the 2007 season. Leaflet samples were randomly taken from the lower, the middle and the top levels of Nabotsif, Sokary, Kalas, and Sakiey varieties. Twenty leaflets were taken from each cultivar (5 leaflets/date palm) one time and date palm left free from any acaricide application. Samples of date leaflets were taken just before 
any application of the above mentioned acaricides and after one month.

\section{RESULTS AND DISCUSSION:}

\section{1-Occurrence and fluctuation of dust mite, $O$. afrasiaticus on fruits:}

Data in table (1) and the corresponding figure 1 revealed the occurrence of $O$. afrasiaticus mite on date palm cultivars during2007 in EL-Karg at Riyadh Governorate. Data showed that the active period of $O$. afrasiaticus mite occurred throughout the period from the first half of March until second half of October. Data revealed that the mean number of mites reached its maximum with 9095 mites/100 dates on the $26^{\text {th }}$ of July. The population then decreased gradually till mid October with 124 mites/100 dates. Also the mean percentage of infestation begins after $2^{\text {nd }}$ week of March reached $3 \%$, while it was $80 \%$ on the $3^{\text {rd }}$ week of October. Palevsky et al., 2005 found $\boldsymbol{O}$. afrasiaticus on fruit between mid-July till the end of August, when pest populations peaked.

Data obtained in the present work are wholly in agreement with those obtained by AlJabr et al 2001, who reported that,during the period from June to August, the dust mite $O$. afrasiaticus Mcg. was the most abundant mite species which infested the bunches and leaflets of the tested date palm cultivars in AL-Hassa oasis. Hussain 1969 reported that peak infestation in Iraq occured around the middle of July.

The peaks of population of this mite depending not only on climatic conditions but also on the type of crop found as a host for the mite during a certain periods of the year and this host might be suitable for date mite in a certain stages during all its life.

Mite phonology is affected by date cultivars, but the relationship between fruit charac- teristics and mite population development is unknown. Palevsky et al. (2005) found that yearly climatic variations could be responsible for phonological asynchrony between the pest and fruit development.

2-The efficiency of the botanical compound (Biaco) as compared with some chemical acaricides against $O$. frasiaticus on fruits of some date palm cultivars:

The average reductions in the dust mite numbers, during the course of the present study, are presented in (Table 2).

Data showed that all tested acaricides gave a satisfactory results after applications, regardless of date cultivars. Statistical analysis of the data revealed significant differences between botanical compound (Biaco) and the other acaricides. The mean number of dust mites on fruits_reduced from about 21.90 mites in control to $5.80,8.75,9.25,9.55$ and 12.5 mites/100 dates in Baico, Amitraz, Vertimec, Perpol and Salocide treatment, respectively.

Take into account the acaricide types and the date cultivars, data of the reduction in the numbers of this mite species demonstrated differentiation in the acaricide potentiality according to the cultivars of date. Good results were achieved when applied all acaricides, while Biaco (1-500 ml) generlly gave the best results among the compounds tested against the dust mite. The acaricide (Amitraz) accompanied by (Biaco) was ranked the first, and the accomplished average numbers were 1.60 and 5.00 mites/100 dates when applied on date cultivar of Sokary.

On the other hand, the last orders were occupied by (Salocide and Perpol) with average number ranged from (21.6) to (11.0) mites/100 dates when applied against this mite species on date cultivars of Nabotsif. Research is needed 
the possibility of using other safer methods of control the pest by abotanical compound (Baico).

Regardless of the tested acaricides, the statistical analysis show significant differences among the tested date varieties, considering of reduction in number of dust mite population. These differentiations may be attributed to the morphological and physiological variation among date palm varieties, which may affect their responses to acaricide treatments for controlling the dust mite.

Anyhow, from the previously mentioned results, it can be concluded that both date cultivars and type of acaricides affected the reduction on the numbers of date mite infesting date palm. The variation of cultivars towards pest infestation may be due to antibiosis, morphological and physiological characteristies of plant, the number of, hair, and plant age (Zaren, 1987). DePew (1960) reported that Kelthane and Trihion provided high initial mortality of $\boldsymbol{O}$. afrasiaticus and were superior to all other acaricides.Nettleton et al. (1978) found dimethoate, etluon. Perpol, dicofol and cartbophenothion most effective, among 13 tested acaricides for controlling $\boldsymbol{O}$. afrasiaticus.

Elmer (1965) found that sulphur used as spray applied to date bunches. Kelthane, cartbophenothion and tetradifon gave a satisfactory control of $\boldsymbol{O}$. afrasiaticus on date palm trees. Atalla and Farrag (1969) reported that kelthane $18.5 \%$ EC gave the best results among six compounds tested against the red spider mite. Al-Doghairi and Mohammed (2004) tested some acaricides in date palm plantations in Al-Gassim, Saudi Arabia, against the date mite, $\boldsymbol{O}$. afrasiaticus. The overall performance of the acaricides, determined according to their ability to reduce the mite infestations comparing with the control throughout the experimentwere (96.8, 96.3, 95.2, 83.8, 81.7, 80.6, 79.0 and $30.2 \%$ ) for Transact, Kelthane, Neoron, Perprol, Tedion, Microthiol, Top Cop and Ekatin, respectively.

3-The efficiency of the botanical compound (Biaco) as compared with some chemical acaricides against $O$. afrasiaticus on leaflets of some date palm cultivars:

Data (Table 3) show the reduction in average numbers of the dust mite caused by certain acaricide treatments on leaflets of four date palm varieties. According to the overall average reduction in numbers, throughout the experimental periods, results indicated that the tested acaricides ranked generally the same sequential on Nabotsif, Sokary, Kalas, and Sakiey varieties. The reductions in number of the dust mite on leaflets of botanical, (Biaco) were 17.6, 3.8, 10.6 and 12.6 dust mite/ 5 leaflets. Biaco was ranked the first one and was effective throughout the experiment, while Salocide EC (150 ml.) was exhibited less efficacy when applied against this mite species on date cultivars of Nabotsif, Sokary, Kalas and Sakiey date varieties $(26.2,14.40,20.10$ and 18.80 dust mite/ 5 leaflets) respectively Table (3).

The morphological and physiological variation among leaflets of date palm varieties may be affected their responses to acaricide treatments for controlling dust mite. Markedly differences among the tested cultivars were observed when infested with this mite. 
Table (1): Mean percentage of infestation and total number of dust mite, $O$. afrasiaticus on fruits/100 dates of two date Palm cultivars (Sokary, Nabotsif) in El-Karg region at Riyadh Governorate, 2007 season

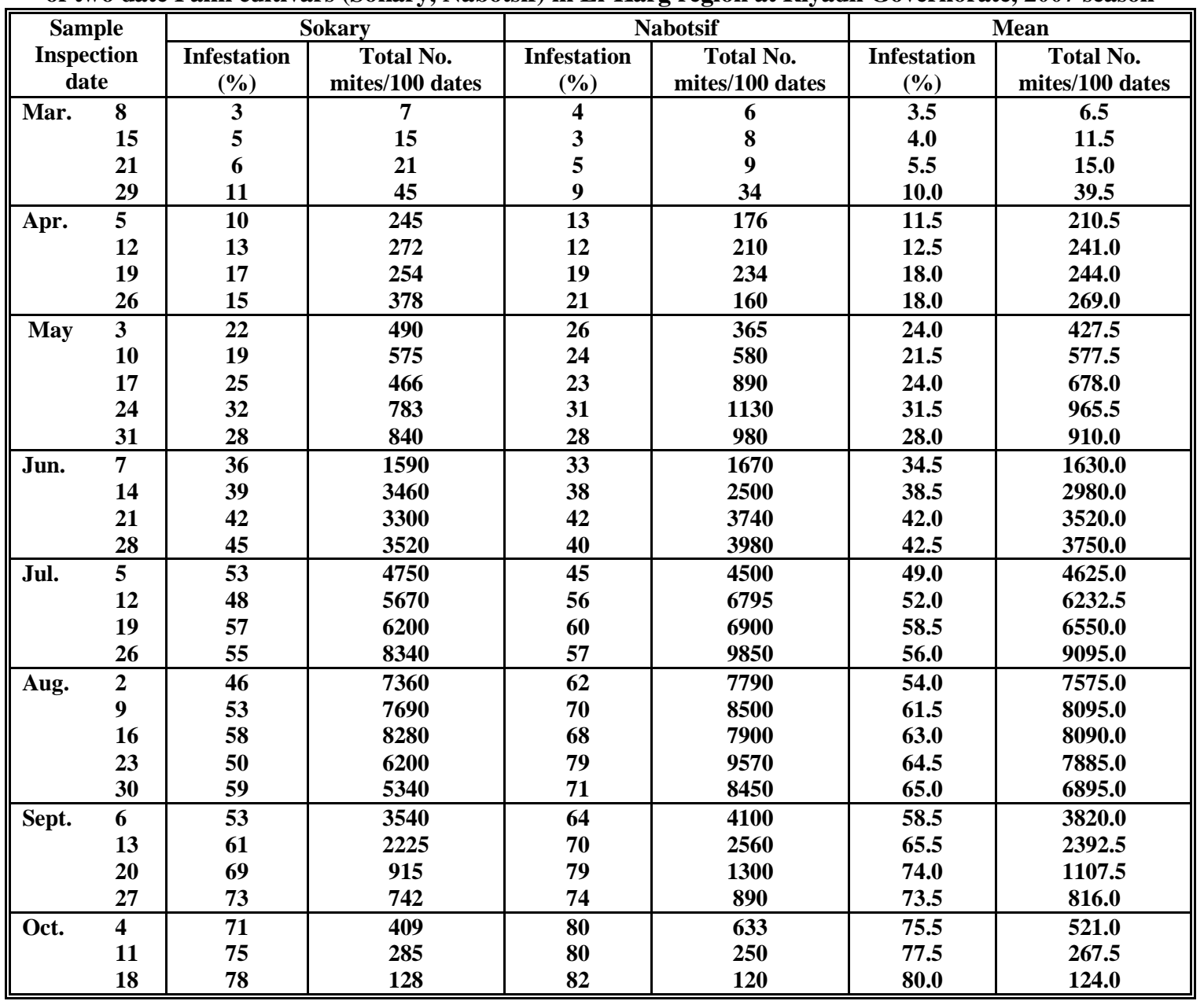

Table (2): Average numbers of dust mite population on different fruit date palm cultivars resulted from application of certain compounds, Riyadh region, Saudi Arabia, 2007 season

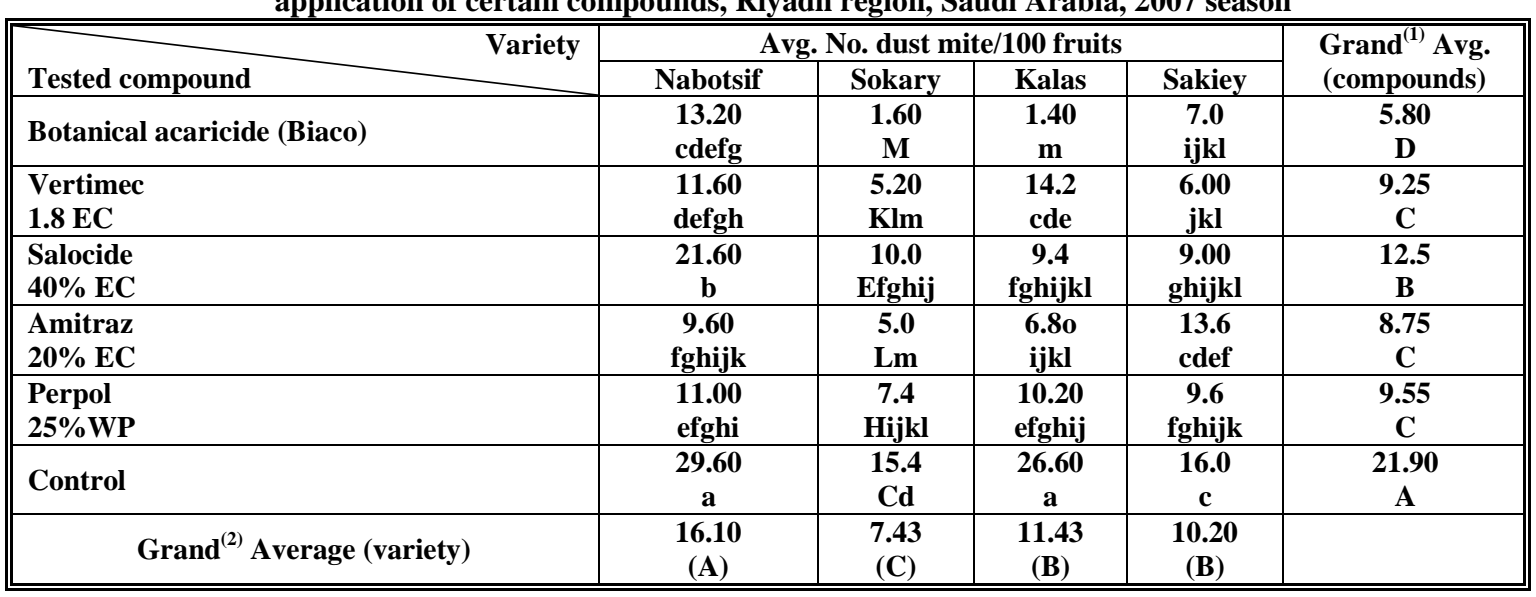

(1\&2) Means followed by the same letter, within the same column or row, and interaction individually are not significantly different at $0.05 \%$ level of probability. 
Ass. Univ. Bull. Environ. Res. Vol. 12 No. 2, October 2009 
Table (3): Average number of dust mite population on different leaflets date palm cultivar resulted from application of certain compounds, Riyadh region, Saudi Arabia, 2007 season

\begin{tabular}{|c|c|c|c|c|c|}
\hline \multirow{2}{*}{$\begin{array}{ll}\text { Tested compound } & \text { Variety } \\
\end{array}$} & \multicolumn{4}{|c|}{ Avg. No. dust mite/5 leaflets/date palm } & \multirow{2}{*}{$\begin{array}{l}\text { Grand }^{(1)} \text { Avg } \\
\text { (compounds) }^{-}\end{array}$} \\
\hline & Nabotsif & Sokary & Kalas & Sakiey & \\
\hline Botanical compounds (Baico) & $\begin{array}{c}17.60 \\
\text { Efg }\end{array}$ & $\begin{array}{c}\mathbf{3 , 8 0} \\
\text { I }\end{array}$ & $\begin{array}{c}10.6 \\
\text { gh }\end{array}$ & $\begin{array}{c}12.60 \\
\text { fg }\end{array}$ & $\begin{array}{c}11.15 \\
\text { D }\end{array}$ \\
\hline $\begin{array}{l}\text { Salocide } \\
40 \% \text { EC }\end{array}$ & $\begin{array}{c}26.20 \\
\text { Bc }\end{array}$ & $\begin{array}{c}14.40 \\
\text { Efg }\end{array}$ & $\begin{array}{c}20.10 \\
\text { cde }\end{array}$ & $\begin{array}{c}18.80 \\
\text { def }\end{array}$ & $\begin{array}{c}19.90 \\
\text { B }\end{array}$ \\
\hline $\begin{array}{l}\text { Perpol } \\
25 \% \mathrm{WP}\end{array}$ & $\begin{array}{c}16.40 \\
\text { Efg }\end{array}$ & $\begin{array}{l}17.0 \\
\text { Efg }\end{array}$ & $\begin{array}{c}13.20 \\
\text { efg }\end{array}$ & $\begin{array}{c}13.20 \\
\text { efg }\end{array}$ & $\begin{array}{c}14.95 \\
\mathrm{C}\end{array}$ \\
\hline Control & $\begin{array}{c}46.60 \\
\mathrm{~A}\end{array}$ & $\begin{array}{c}29.20 \\
\text { B }\end{array}$ & $\begin{array}{c}24.40 \\
\text { bed }\end{array}$ & $\begin{array}{c}\mathbf{5 0 . 6 0} \\
\mathbf{a}\end{array}$ & $\begin{array}{c}37.70 \\
\mathbf{A}\end{array}$ \\
\hline Grand $^{(2)}$ Average (variety) & $\begin{array}{c}23.57 \\
(\mathbf{A})\end{array}$ & $\begin{array}{c}14.13 \\
(C)\end{array}$ & $\begin{array}{c}16.70 \\
\text { (B) }\end{array}$ & $\begin{array}{c}25.33 \\
\text { (A) }\end{array}$ & \\
\hline
\end{tabular}

(1\&2) Means followed by the same letter, within the same column or row, and interaction individually are not significantly different at $\mathbf{0 . 0 5} \%$ level of probability.

\section{REFERENCES:}

Al-Doghairi A. Mohammed (2004): Effect of Eight Acaricides Against the Date Dust Mite, Oligonychus afrasiaticus (Mcgregor) Acari: Tetranychidae). Pakistan J. Biol. of Sci. Vol.: 7 - Issue: 7.

Al-Jabr A. M., A. A. Al-Shagag, M. Al-Bazer and A. A. Al-Samhan (2001): Survey of mites infesting some date palm cultivars. (Phoenix datcylifera L.) in Al-Hassa Oasis, Kingdom of Saudi Arabia. King Faisal University, Al-Hassa. Saudi Arabia, E-mail: ahsares@agrwat.gov.sa

Atalla, E. A.R and A.M. Farrag (1969): Field test of some acaricide against the red spider mite, tetranychus telarius (Comlex) on tamatoes Agric. Res. Rev. 47:149- 151.

DePew, L. J. (1960): Control of O. apratensis attacking winter wheat in western Kansas J. Econ. Entomol, 53:1061-1063.

Elmer, H.S. (1965): Banks grass mite $O$. pratensis on Ate in California. J. Econ. Entomol., 58:531- 534.

Gerson, U.; A. Venezin and D. Blumberg. (1983): Phytophagous mites on date palm um in Israel. Fruits, 38: 133-135.
Hussain, A.A. (1969): Biology of paratetranychus afrasiaticus (McGregor) (Acari: Tetranychidae) infesting date palms in Iraq. Bull. Soc. Ent. Egypt, 53: 221-225.

Mohamed, S.G. (2005): Pests of the Date Palm (Phoenixdactylifera) Plant Protection Expert (Entomologist) saeedgassouma@ hotmail.com.

Nettleton, W.A, F.P. Hain and R.J. Monroe (1978): Field evaluation of acaricides for control of Oligonychus urnguis (Acarina: Tetranychidae) in Fraser Fir plantations. J. Econ. Entomol., 71: 113-114.

Palevsky, E; O. Ucko; S. Pales; S. Yablonski and U. Gerson (2003): Evaluation of control measures for Oligonychus afrasiaticus infesting date palm cultivars in the Southern Arava Valley of Israel. Hebrew University of Jerusalem, POB 12, Rehovot 76100, Israel Available online 7 November 2003.

Palevsky, E; H. Borochov-Neori and U. Gerson (2005): Population dynamics of $O$. afrasiaticus in the southern Arava Valley of Israel in relation to date fruit characteristics and climatic condition 
Dept. of Entomology, Agricultural Research Organization, Newe Ya'ar Research Center, PO Box 1021, Ramat Yishay 30095, Israel.

Saleh, M.R.A and M.M. Hosny (1979): Obsevation on Oligonychus spp. Occurring on date bunches (Acari: Tetranychidae). Ian Shams Univ. 1979.
Talhouk, A.S. (1991): On the management of the date palm and its arthropod enemies in the Arabian Peninsula. J. Appl. Entomol., III: 514- 520.

Zaren, N. (1987): Evaluation of six cotton cultivars to thrips and leafhopper. Iran Agricultural Research (1985, recd.1987) 4, 89-97.

$$
\begin{aligned}
& \text { تو اجد حلم الغبار Oligonychus afrasiaticus Mcg على ثمار وأوراق } \\
& \text { بعض أنواع نخيل التمور وتقييم فاعلية المركب الحيوي بائيك } \\
& \text { مقارنة ببعص المركبات الكيمائية الأكاروسية فئية } \\
& \text { صالح بن عبد الله الدوسري } \\
& \text { قسم وقاية النبات - كلية علوم الأغذية والزراعة - جامعة الملك سعود }
\end{aligned}
$$

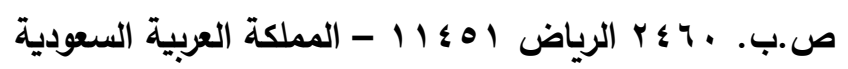

تواجد حلم الفبار على ثمار وأوراق بعض أنواع التمور بمنطقة الخرج بمدينة الريـاض بالمملكة العربية السعودية

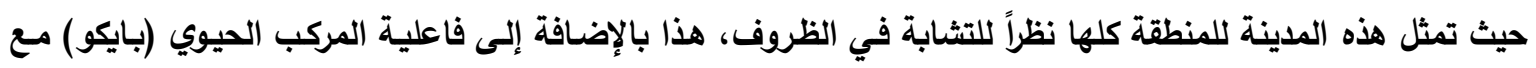

$$
\begin{aligned}
& \text { بعض المركبات الأكاروسية خلال موسم V. V. . . . . }
\end{aligned}
$$

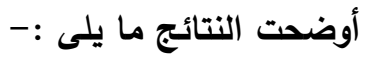

1- وجد أن بداية فترة النشاط لطلم التمور Oligonychus afrasiaticus Mcg في خلال النصف الأول من شهر مارس

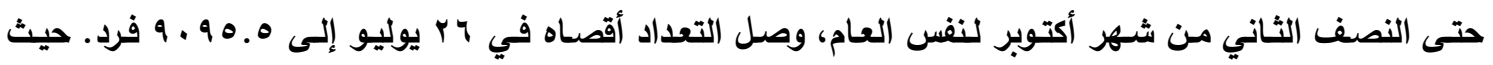

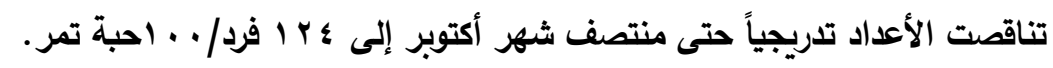

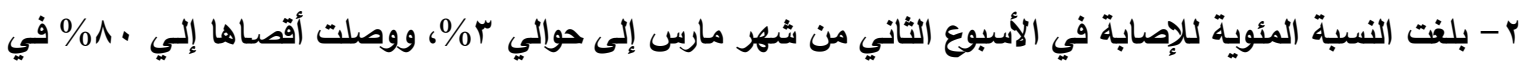

$$
\text { الأسبوع الثالث من شهر أكتوبر لنفس العام. }
$$

r- من التحاليل الإحصائية اتضـح أن هناك فروق معنويـة عند المعاملة بالمركب الحيوي "بايكو" بالمقارنة بالمركبات

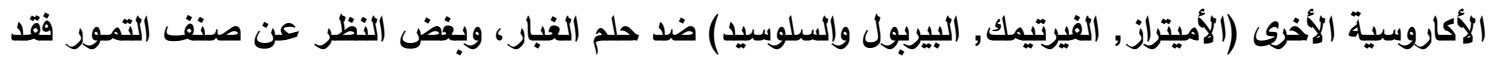

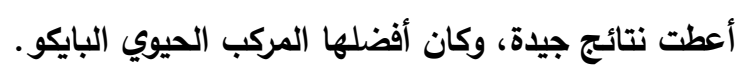

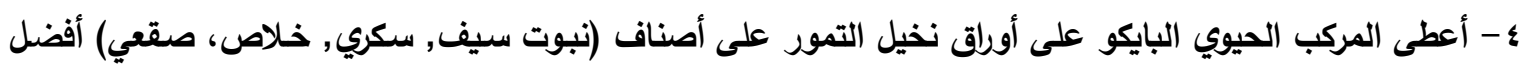

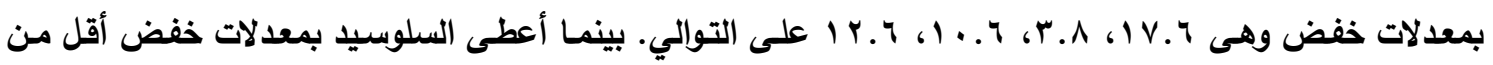

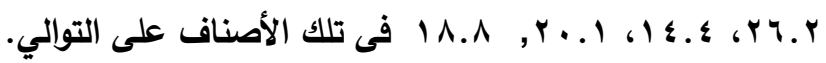

